\title{
Relationship between social support of parents and self concept with stability of career decision
}

\author{
Regina BM Nainggolan ${ }^{1}$, Firman ${ }^{2}$, Yeni Karneli ${ }^{3}$ \\ ${ }^{123}$ Universitas Negeri Padang, Padang - Indonesia, (regina_nainggolan@ymail.com)
}

\begin{abstract}
Background of this study is motivated by the students who have many problems about have no readiness, have no knowledge, and have not been informed about employment opportunities in out of school education. The study aims to reveal that there is a relationship between parental social support and self concept with stability of career decision. The study uses quantitative method of correlational. The Subject of this study is a consisting of 75 people. The research instrument used is a questionnaire and used a Likert scale. The data of this study are analyzed using multiple regression. The results of this study indicate that there is a very significant relationship between social support of parents, Self Concept with Stability of Career Decision.
\end{abstract}

Keywords: Social support of parents, self concept, stability of career decisions

\section{Introduction}

Stability of career decision is a matter that determines the future. The stability of one's career decisions carefully formed through knowledge and supported by information regarding the work to be selected. Students who have entered college must have the skills, must have extensive knowledge and must be able to master the technology so that students can compete in the working world even able to create their own jobs and can reduce unemployment rates in college.

In fact, many college graduates are unemployed because there is an imbalance between university graduates with a qualification profile ready workforce. According to the Ministry of Labor of the Republic of Indonesia (in Tribunnews.com, 2017) explains that in one year graduates nationwide reach 750-800 people. That is still a lot of difficult students find jobs in accordance with its competence, if seen again from the Central Bureau of Statistics (in Kompas.com 2017) that the number of unemployed college graduates reached 856.644 people, which means that the unemployment rate of college graduates is still quite large, as well as the Central Bureau of Statistics of North Sumatra province.

The Central Bureau of Statistics of North Sumatra Province explained that the unemployment rate in February 2016 reached 6.49\%, while in February 2017 reached 6:41\%, it decreased by $0.09 \%$. That is a decrease in the unemployment rate of college graduates in North Sumatra is still low. One college in the State University of North Sumatra, Medan.

Students who entered department of Non-formal Education should have the readiness and confidence in determining the choice of a career, should have the interest, abilities, knowledge about 
him and know the environment of the world of work, should have information about the profession to accommodate undergraduate non-formal education, should have the competence so that after graduated from non-formal education student with a stability of career decisions that will be undertaken and obtain employment in accordance with the fields already provided.

Based on the results of research conducted by Arbarini and Yusuf (2008) explained that the capacity of non-formal education alumni in the working world is still low. It can be seen from some of the statement submitted on the constraints faced by graduates is the lack of information about job vacancies for non-formal education, confused to find work in accordance with non-formal education field, while employment opportunities for non-formal education alumni are very small, if looking for another job, there are still concerns in the competence, employment opportunities for graduates of non-formal education is often occupied by the other courses. In fact, non-formal education graduates lacked sufficient competence specifications.

The next phenomenon of the research conducted by Arbarini, Fakhrudin and Ekosiswoyo (2010) this study focused on the difficulty in obtaining employment due to the limited information of job vacancies for non-formal education graduates, the general public is not aware of the competence of non-formal education graduates and non-formal education programs have no specific skills. Based on the phenomenon described in the preceding paragraph it can be concluded that students of nonformal education must stabilty career after graduation from college so that the job to be faced in accordance with the field of non-formal education.

Stabilty of appropriate career decisions must be in accordance with the ability of the students. Meanwhile, according to Brown (in Wicaksono, 2010) also explains the stability of career decisions is supported by the family. Parents should encourage their children to discuss their career choices. Social support of parents is a support that comes from families which can make individuals receive information assistance and as a place to discuss about employment opportunity. Wayne \& Slocum's research (in Husain, 2013) also explains that students can be directed in establishing career decisions based on available information from parents and the environment. Further confirmed by the results of research Istifarani (2016) which explains that family support has a high category with a percentage of $78,71 \%$.

According to Pietrofesa (in Wicaksono, 2010) explains that the factors in student career stability include internal factors, namely intelligence, self-confidence, self-concept, and values adopted. Selfconcept is a supportive process to find himself in the interests, abilities, value of a job and can find advantages and disadvantages about himself with the demands of a student career in the future.

Based on that exposure, Munardji strengthened by the study (2014), which explains that each employee can cultivate and develop all the skills, intellectual, insight, motivation, and dedication of the employee in the position of the work he is doing. Therefore, a person in establishing his career must have self-concept or ability to judge, understand himself to be able to determine the steps to consolidate the right career decisions. Based on interviews conducted with student class of nonformal education in academic year 2017 State University of Medan, known to have difficulty stabilty a career decision. Students who have chose the non-formal education has not been able to stabilty career decisions due to lack of job information after graduation, less information from parents, high school environment about job opportunities for non-formal education graduates, employment information about non-school education is inconsistent, lacking readiness in choosing an education majors.

\section{Method}

This research is a descriptive quantitative research with correlation method. The population of this study is a limited population of all students in the first semester majored of out of school education, sample consist of 75 people. The instrument used is a questionnaire and the scale used is Likert scale. 
To know the relationship of 2 independent variables to 1 dependent variable then the data is analyzed by multiple regression.

\section{Results and Discussion}

Testing Data Analysis Requirements

Test requirements analysis conducted in this study is a test of normality, linearity test, and multicollinearity test.

1. Normality Test

Normality test by using Kolmogorov Smirnov method which shows that the variable is normally distributed, with Asymp value Sig. The social support of the parents is 0.358 , the self-concept is 0.513 , and the stability of career decisions is 0.204 .

2. Linearity Test

The result of linearity test shows that the data of social support of parents variable, and self concept with career decision making is linear with Sig. $0.000 \leq 0.05$.

3. Multicollinearity Test

The result of multicollinearity test shows that social support of parents VIF value of 2.057 and selfconcept VIF value of 2.057.

\section{Discussions}

Based on the results of the study there is a significant positive relationship between social support of parents and self-concept with the Stability of career decisions. In the following sections it will explained.

The relationship between social support of parents and self-concept with the Stability of career decisions

The analysis results of social support of parents and self-concept with the Stability of career decisions. The result shows that the social support of parents and self-concept is significantly related to the stabilty of career decisions by 0,762 .

Relationship betweeen social support of parents and self-concept with the Stability of career decisions

The result shows that the social support of parents and self-concept is significantly related to the stablity of career decisions. These findings were obtained based on a series of data analyzes showing that the relationship of parents social support and self-concept with stabilty of career decision was $68.9 \%$. It means, the social support of parents and self-concept is one of the factors associated with student career stability.

Referring to this research it can be understood that the higher social support of parents and selfconcept, the higher the stability of career decisions. This means that the social support of parents and self-concept determines the high degree of stabilty of career decisions. This is related to the Berzonsky's theory (1981) which explains that there are several factors that affect self-concept in establishing student career decisions, ie age, education level and environment. The environment in here is the social environment of parents. The concept of self is formed because of the interaction between the individual with the parents (father and mother).

Shetzer \& Stone (1980) explain that in deciding a career will always be related to several factors that influence career decision making, the factors as follows: (1) The ability of the intellectual, (2) Talent, (3) Family (4) Personality, (5) The concept of self, (6) Interest, (7) Aspiration and reality, (8) Hope, and (9) Sex differences.

The research result conducted by Greenhaus and Callanan (2006) state that support gained in close family relationships can enhance career exploration in childhood and carry on into adulthood, 
through the support of parents can help the development of career exploration that can be used by individuals in establishing career decisions. This is supported by Taylor, Peplau \& Sears (2012) research which states that social support of parents has a very strong influence in the consolidation of student career decisions. Students who have the support of parents will be able to establish career decisions well and correctly, if students get lack support from parents then the student has not been able to establish a career decision well and correctly. Further supported by widyastuti research (2013) that there is influence of social support of the family on the stability of career decisions, it means that the higher the family social support the higher stability of the decision, and the lower the social support of the family the lower the stability of student career decisions.

The self concept also has several aspects that support the establishment of student career decisions, namely aspects of knowledge, aspects of expectations and aspects of self-assessment. Hurlock (1999) explains that self-concept is very influential in the consolidation of career decisions. A person who sees himself positively about his self-concept will see success as his business. Conversely someone who lacks self-concept, then it is difficult to decide his career and see himself as having no ability and less able to realize his dreams so that someone resigned to his future. Gladding (2012) believes that the importance of self-concept to mark one's career choices about work. People's views of themselves are reflected in what they do.

\section{Conclusions}

Based on the findings and discussion of research results, it can be concluded that the social support of parents and self-concept with the establishment of career decisions have a significant relationship. It shows that to improve the social support of parents and self-concept, students need to improve the consolidation of career decisions.

\section{References}

Arbarini, M. \& Amin, Y. (2008). Studi Tentang Daya Serap dan Etos Kerja Alumni Pendidikan Luar Sekolah Fakultas Ilmu Pendidikan. Jurnal Penelitian. Semarang.

Arbarini, M, Fakhrudin, \&Ekosiswoyo R. (2010). Tracer Study Alumni Pendidikan Luar Sekolah Fakultas Ilmu Pendidikan. Jurnal Penelitian. Semarang: UNNES.

Wicaksono. L. (2010). "Pengaruh Prestasi Belajar Terhadap Pengambilan Keputusan Karier". Jurnal Penelitian. Pontianak: Universitas Tanjung Pura.

Husain, S. \& Rafia, R. (2013(. Role of Parental Expecctation and Career Salience I Career Decision Making.Journal of Behavioural Sciences. (Vol.23, No.2).

Istifarani. (2016). "Pengaruh Dukungan Keluarga Terhadap Pengambilan Keputusan Karier Siswa Kelas X Di SMK Negeri 1 Depok" ARTIKEL E-JOURNAL.

https://www.Kompasiana.com Banyak Sarjana Menganggur, Apa dan Siapa yang Salah?. Diakses pada tanggal 16 Februari 2018.

https://Tribunnews.com Pengangguran di Indonesia Tinggi Karena Lulusan Perguruan Tinggi Terlalu Milih Pekerjaan. Diakses pada tanggal 16 Februari 2018.

Munardji. (2014). “Urgensi Konsep Diri Dalam Pengambilan Keputusan Karier”. Jurnal Edukasi. Vol 02 No 02.

Berzonsky, M. D. (1981). Adolescent Development. New York: Macmillan Publishing Co.

Shertzer, B \& Stone. S. C. (1980). Fundamental of Counseling. Boston: Houghton Mifflin Company.

Greenhaus, J.H., Callanan, G.A. (Editor). (2006). Encyclopedia of Career Development. Vol. 1: 103-107. London: Sage Publicant, Inc

Taylor. E. S. Peplau, A. L. \& Sears, O. D. Psikologi Sosial. Terjemahan oleh Tri Wibowo. (2012). Jakarta: Kencana Media Group. 
Widyastuti, R. J. (2013). "Pengaruh Self Efficacy dan Dukungan Sosial Keluarga Terhadap Kemantapan Pengambilan Keputusan Karier Siswa". Jurnal BK UNESA. Vol 03 No 01.

Hurlock. (1999). Psikologi Perkembangan. Alih Bahasa Tjandrasa dan Zarkasih. Jakarta : Penerbit Erlangga.

Gladding, S. T. (2012). Konseling: Profesi yang menyeluruh. Jakarta: Indeks. 